\author{
Elvira Küün \\ Narva College of University of Tartu, Estonia
}

\title{
THE DIVERSITY OF IMMIGRANT IDENTITY AND THE ASPECTS OF THE DESIGN THEREOF
}

Summary. The article provides an overview of the design of identities, predominantly based on the level of the individual. The purpose of this article was to identify the ethnic identity of informants, using the aspect of language choices as an instrument of linguistic identity, as well as to look at the causes of linguistic identity choices, the functions of ethnic identity from the point of view of the informant and the reasons for changing the identity over time or for consciously changing or maintaining it. It is well known that in today's world of ever-weakening national borders, multiculturalism and multilingualism are a common phenomenon. There have been no arguments for a long time over whether one has to learn several languages, or any doubts whether we should be even a little bit familiar with the culture of people from other nationalities living next to us. At the same time, multiculturalism brings along challenges and sometimes also tensions (Muldma, 2009). Self-determination, or identity, can mean all aspects of oneself, such as appearance, personality, abilities, gender, and ethnic groups. In the case of ethnic identity, it has been observed along with growing, the perceptions of children change over time. Awareness of one's nationality develops with awareness of others (Smith et al., 2008, p. 195). People's attitudes and values are largely developed in childhood, and we need time to get adjusted to everything new, all changes need internal management of the person - and some major changes need the intervention of the society. The method used to conduct the research was written interviews.

Keywords: ethnic identity; identity switching; immigration; language choice; minority languages.

\section{Introduction}

Today's globalizing world causes changes in the traditional way of life and worldview. In addition, the postmodern world also requires the individuals to have the ability to integrate into other cultures in addition to their own folk culture, simultaneously understanding and respecting them (Muldma, 2009). Every individual is a representative of a future multicultural society, and besides the formation of his or her national/ethnic identity, it is essential to develop the values, attitudes and personal qualities (tolerance, empathy, civic sense and civic consciousness, etc.) necessary for coexistence that is most successfully developed through intercultural dialogue (Loide, 2015). At the same time, according to Vseviov (2009), all cultures, which at first glance stand alone, are mainly "multicultural" and there is no "pure" culture (if we conditionally leave out some single groups of people isolated from the rest of 
the world, for instance, in the Amazon or elsewhere in the rainforests).

General globalization means that multiculturalism has become a regular part of ordinary life. Everyone has to define internally who he or she is in the place where he or she lives. An individual needs to know and feels for himself or herself whether he or she constitutes a part of the history of the region, and what kind of relationship is there between his or her family and his or her location. These are the two main issues between identity and the environment. For self-image, it is important for everyone to feel that he or she is an accepted personality in the very place he or she is. At no national level should the aspect of ethnic pride (Valk, 2017), which plays a role in the development and preservation of national self-awareness, be ignored.

The relationship between a human being and a place develops through their beloved people, work, language, and culture. What is important is the dialogue that the individual has with other people and the universal language of communication so that communication and sharing of the cultural space can become possible. If we look at the problem from a societal point of view, the question is really about building a community identity based on a sense of belonging (Vasama, 2003).

The state determines the basic codes of the collective identity of its territory, a particular "legend" into which the individual tries to adapt himself or herself. For example, when it comes to the Finnish identity, people often talk only about the "right" Finnish identity and mention the Finnish Swedes perhaps only in a couple of words. Sámi or Gypsies as parts of the Finnish identity are often forgotten, not to mention immigrants who have brought a new layer of the Finnish identity over recent decades. But, for example, Estonians in Estonia no longer have the same identity as they used to have a hundred years ago. Paasi (1997) recognizes that socio-spatial identity is always the result of social and political struggles that are context-related and continually changing. Figuratively speaking, local people are increasingly becoming global and global people are increasingly becoming local (ibid.). 


\section{Contact points between identity and social psychology}

Since identity is originally a term belonging to the realm of psychology and sociology, it should be considered more closely in the context of social psychology (see also Uudeberg, 2009). Building an identity at an individual level is a multi-layered psychological model, and it is impossible to map it quantitatively to the full extent. In the case of an individual, there is theoretically a different identity for any moment in time, which is made up of sub-identities relevant to precisely this situation (Sudman, Bradburn, \& Schwarz, 1996).

Thus, the formation of identity and comparing it with oneself in defining a similar identity is highly subjective and dependent on a specific context. Rousseu' (2006) has pointed out that identity cannot be quantified unambiguously; but estimates and opinions can be measured. The most basic, existential identity of an individual is entirely unchanged, but the identity that is predominantly generated through interaction is changing over time.

Of course, the process of perception is a psychological phenomenon. According to the pluralistic approach to perception research (White, 1998), individual experiences may have an impact on a particular individual, and the process of thinking is unconsciously influenced by cultural socialization (Sein, 2004, p. 9). From the point of view of pluralism, there is one objective reality, which, however, due to the multitude of variables and complex interrelations between the variables in the system, cannot be described directly and precisely (ibid.). Other theories of ethnic identity have a functional approach. For example, the model developed by Phinney (Phinney, Dupont, Espinosa, Revill, \& Sanders, 1994) assumes that the persistence of ethnic identity is desirable because it prepares for a sense of belonging and psychological well-being, which ultimately should lead to the development of a positive in-group identity and maximum self-esteem.

The central idea of constructivist schools is the notion that there is no one objective reality. The classification of single and absolute identities is made impossible by the plurality of participants, experiences and perspectives, the construction of identities over time and paradigmatic influences. Language is one means of constructing the identity of an individual (Tabouret-Keller, 2000). 
According to constructivism, people behave towards objects (and other people) according to the meaning of the subject or object for them. Every participant in a social communication process has its own identity - a relatively stable role-specific understanding and expectations of themselves, which are developed in comparison to others (Wendt 1995, p. 46). The author of this article agrees with the principles of the constructivist school of identity, and in this work, the concepts of identity are based on the corresponding ideas.

\section{Ethnic self-determination and the link between language and identity}

Ethnic identity has been defined as a sense of belonging to an ethnic group of a particular group (Liebkind, 1995). Ethnic identity is shaped by a number of factors that are unique to each nation and historically evolved. This includes, for example, tradition, common self-awareness and collective opposition to other nations (Rannut, Rannut, \& Verschik, 2003). Ethnic identity is determined by the knowledge of who one is and what one is believed (Valk \& Karu, 1999) to be. Language and culture based on it are also a characteristic of ethnicity (Rannut et al., 2003). Thus, linguistic identity also forms part of ethnic identity (Kidd, 2002).

Many scientists agree that language is the most essential identity marker (see, e.g., Iskanius, 2005; Fishman, 2001; Bilaniuk \& Melnik, 2008). The child does not choose his or her mother tongue; he or she acquires and learns in his or her own environment. Language is also contextual; we use different languages in different situations. In our family, we may use a different language from the one that we use in the workplace; the language of the text message on a mobile phone, or the language used in the media may differ from the language used at home and at work. The world has become a field of multilingualism, where common understanding is sought from a common language. For example, Sanna Iskanius (2005) has described where young people with Russian roots who have lived in Finland for some time have begun to use a mixture of Finnish and Russian, and a relevant study performed for a Master's thesis showed that the linguistic identity of people living in different places in Finland has changed. In this case, this study showed the relationship of the language identity of Russians studying in vocational schools with 
an ethnic identity, linguistic and national position, where, over time, they have started to move away from their own language of origin. There are some who, after living in the country of destination for a more extended period of time, have become somewhat culturally divided in the course of acculturation, and are quite happy with it, but there are also those who have become marginalized and may experience an identity crisis due to the feeling of rootlessness (see also Baker, 2006).

A language is also a tool of governance and power; with the help of language skills, one can create a specific status for themselves in different environments. Identity can also be situation-based, where, according to different communication situations or partners, a specific identity is constructed for oneself (see, e.g., Toivanen, 2009). One becomes the person he or she makes himself or herself, by learning through knowing the world (Gustavsson, 2000).

In different studies, one of the most important features of ethnic identity is the existence of one's own language of origin, even if language skills are relatively low and this language is only marginally used (see, e.g., Bilaniuk \& Melnik, 2008; Küün, 2014).

Since language is one of the most marked features of an individual, language represents and mediates the most decisive elements of human identity (Hoffmann \& Ytsma, 2004). However, the essence of multiple identities is well illustrated by a quote from Ummaya Abu-Hannah, who has lived in Finland for over 20 years, "Sinut" (2007, pp. 48-56):

I was born in Israel, in a Palestinian Christian and atheist family. I am Arab, but not Muslim; a Christian but not a believer; an Israeli, but a Palestinian woman. I have lived practically all of my adult life in Finland. Right now I'm a FinnoPalestinian. I consider myself as a Finn and an Arab in my home, and it consists of a new way to define three places.

\section{Functions of ethnic identity}

Different functions are attributed to ethnic identities, such as supporting the psychological well-being of the individual, the possibility of achieving a better status in the society and helping to prevent negative stereotypes. Functions of ethnic identity are important in part because they provide us with 
information about which individual self-attitudes and sub-identities we have used to maintain self-esteem.

Studies of ethnic identity show that it is subjective and insecure. It has been created through a combined process in the sense that an individual or group and bystanders together determine the ethnic identity (see e.g., Barth, 1969; Smith, 2016). Since ethnic identity is seen as subjective and insecure/inconstant, it is not surprising that the contradiction in labeling represents the unity of ethnic identity (commonality). For example, in one study, which was based on informants from the Spanish population of New Mexico, $17 \%$ of secondary school students interviewed were those who in the first stage recognized their identity as Hispanic, but in another study two years later, they chose a non-Hispanic identity (Eschbach \& Gomez, 1998). Generally, identities that generate negative stereotypes are not accepted (or at least not preferred) (Doan \& Stephan, 2006).

Doan and Stephan (2006) have mentioned that the choices of ethnic identity are influenced by the avoidance of the emergence of negative associations, which could otherwise lead to discrimination. Waters (1990) argues that specific ethnic identities have been selected because they are considered more socially respected than other available choices.

Of course, it cannot be assumed that people perceive themselves as belonging to clearly defined categories. Instead, the introduction of identifying categories allows us to look at the development opportunities provided for in the Estonian context.

The second part of the article is made up of the empirical half of the study, and through it the paper adds some important information on the language and identity choices of ethnic groups living in Estonia.

\section{Objectives and research method of the study}

The main purpose of this study was to identify the causes of ethnic and linguistic identity choices and to understand the functions of ethnic identity from the participants' perspective. However, it would be premature to make definitive conclusions based on such a small study group. This qualitative study allows one to look into the identity problem of each participant in depth in order 
to establish the relation between the causes and consequences regarding identity at the individual level.

As a research method, a written interview was used. There was a total of 32 questions, whereas the last question provided an opportunity to submit thoughts about their ethnic origin or language. It was possible to answer in both Estonian and Russian.

Eight participants were interviewed in total, who were conditionally selected on the basis of the following criteria: almost all of them were born outside Estonia and started living here at least 14 years ago, except for two participants, one of whom was born in Estonia, but has lived in England for the last 16 years, and one participant who has lived in Estonia for 11 years. The respondents were ensured anonymity and therefore the subjects in the study are coded as: S1 stands for female first respondent, and B1, for example, is the first male respondent, etc., respectively. All respondents were between the ages of 28 and 40 . All of the study subjects were willing to participate in the study voluntarily. The conductor of the study turned to the respondents using their personal contacts.

Involvement of an Estonian-born participant gives a new perspective to the study, helping the reader to better understand the situation of those who have left the homeland, and also helping them to better understand the attitudes of those close to the homeland of immigrants, which surely affect the situation of those surveyed. In general, the selection of participants allows the situation in Estonia to be associated with wider population migration processes that are taking place in the world. (New) immigrants, their values and attitudes, and the processes that take place with them, are a very topical issue both in the European Union and in many other places in the world. The study also examines people of Finno-Ugric origin who have settled in Estonia from Russia. The attitudes, language and identity choices of these people represent an immense number of attitudes and choices of a larger group of people - many other small nations in the world whose language and culture are endangered by the influence of some of the most populous language speakers' communities. The results of the study are important because they also allow a comparison of the attitudes and choices of people of Finno-Ugric origin in the world with a more general situation. 


\section{Results}

The following subchapter provides background information about the people surveyed. Below is the origin and year of arrival in Estonia (or departure from) of each participant.

Four of the participants surveyed in this study were born in Russia (Mari El, Permyak-Komi and Mordovia) and came to study in Estonia in 1999, 1998 and one of them in 2007, as part of the tribal peoples' programme (according to S1: Mordovia; S2: Mari; B1: Permyak-Komi and S3: Mordovia). Three of them originated from a bilingual family, one from a single-language family (S1).

Of these, the first participant, a young woman (S1), belongs to the Erzya-Mordvinian ethnic group and her parents are both of Mordvinian and Erzya origin. She considers her mother tongue to be Erzya-Mordvinian. Her first language is Erzya, the second is Russian and the third is Estonian. In her childhood, she only used the Erzya language as the home language when communicating with her mother, father and grandparents, but also Russian with her brother alongside Erzya. As an explanation, it was added that as she attended a Russian kindergarten with her brother, they also interacted in Russian sometimes.

The mother tongue of Participant S2 (female) is Mari, she belongs to the Mari ethnic group and her parents belong to the same ethnic group. But her first language is Russian, only the second language is Mari, Estonian is the third language, and she is also proficient in Finnish and English (fourth and fifth languages respectively). She only used the Mari language when communicating with her grandparents, but she spoke Russian with her siblings and parents. With this participant it can be seen that the mother tongue and the first language may not always overlap.

A B1 (male) subject under study considers himself to be a PermyakKomi, and his mother and father are both of Permyak-Komi ethnic origin. The first language of B1 is Russian, the second language is Permyak-Komi and the third is Estonian. In his childhood home, he communicated with his relatives in Russian, with the exception of the communication language with his mother, who occasionally used Permyak-Komi as a domestic language 
besides Russian. But Russian remained the main language. Like the previous participants, he came to Estonia to study at about the same time.

The fourth study subject S3 (female) from this group also belongs to the Finno-Ugric ethnic group. For specification it was added that her parents are from Shoksha and her mother tongues are Erzya and Shoksha-Mordvinian dialect. As her first language, she specified the Shoksha dialect, the second was Erzya, and only then Russian as the third language. This shows that this ethnic minority group has been successful in their efforts to preserve their language, albeit to varying degrees, and has managed to refrain from being assimilated into an overwhelmingly larger ethnic group. While studying at school, the study languages were Russian, Erzya, and Shoksha. In her childhood home, her family used the Shoksha dialect. It also shows a strong endeavour to preserve their language. As mentioned before, Russian is the third, not second or first language for the interviewee.

Participant S4 is a woman living in Estonia since 1993 (she was 11 years old then). She came from Germany with her parents to live in Estonia because of her father's work and began studying in an Estonian-language school. Her paternal grandparents were from Mari El and were of Mari nationality, so this participant also had Finno-Ugric roots, although she considers herself a German. She belongs to a German ethnic group, as do her parents and relatives. Her mother tongue is German, and this language is also her first language. When communicating with her parents, she has always only used German. She considers her second language to be Estonian, which she learnt in about a year after settling in Estonia. When she moved to Estonia, she lacked the knowledge of the Estonian language. Participant S4 finds that the fact that there is no large German community in Tallinn could also have contributed to the fast learning of the Estonian state language.

In the case of the sixth participant, B2, it shows that his identity has changed over time for certain reasons. The young man came to Estonia from the Czech Republic in 1995, when the boy was 7 years old. He studied in a Russian-language school in Estonia and considers his mother tongue as Czech, his parents are also Czech (his mother's partner is Russian-speaking and of Russian nationality) and he also considers himself Czech. However, as his first language, he has listed Russian, Czech as the second language, and he is also skilled in English at an advanced level. While living in Estonia, he 
prefers to speak Russian, outside his home he only uses Russian, and Czech at home with his mother (the young man lives with his mother and stepfather, with the latter, the participant communicates in Russian). Having lived in the Czech Republic during his childhood, he used the Czech language as his home language, and he is currently using Czech and Russian simultaneously at home.

The seventh participant, marked as S5, was born in Estonia and grew up in a bilingual family where in her childhood she spoke in Estonian to her mother, Russian with her father, Estonian with her brother and Estonian with her grandparents (maternal) and Russian with her grandparents (paternal). Her mother is Estonian, and her father is Russian. After attaining secondary education, she worked in different countries: in Germany, Austria, Switzerland, France, Norway and England. She has lived in London for 16 years and is married to an Englishman. S5 still considers herself Estonian when abroad, although she admits that she has had situations where she has had difficulty identifying herself. Her first language is Estonian. She currently only uses English at home to communicate with both her child and her husband. While living abroad, she has learnt the English language despite having studied German as a foreign language at school. As a fourth language she lists Norwegian, and fifth French (she lived in France for two years in total, less elsewhere).

The eighth participant B3 was born in Finland but also lived in England for some years. His ancestors were the Sámi Roma. The Finnish language of the participant differs slightly from the Finnish written language, his home language was one of the dialects of the Finnish language, the Sámi dialect. He settled in Estonia in 2003, and his partner is a native English speaker. One of the reasons for settling in Estonia was the fact that the participant's Australian partner had Estonian roots and a well-paying job was found in Estonia. Participant B3 considers himself to be of a strictly Finnish ethnic group, not a Sámi Rom. He regards Finnish as his first language. His second language is English (current home language) and his third language is Estonian.

The participant mentioned last in this study illustrates a high level of globalisation and the scope of multiculturalism of the individual very well. The man is a 40-year-old living in Estonia. He has identified himself as a Finn within the framework of this study (although, five years before the study was 
conducted, he claimed to be a Sámi Rom) and was born in Finland. As mentioned before, the young man has a partner who grew up in England and with whom he became acquainted when living in England. Now both work in Estonia, whereas the latter is an Australian with Estonian roots.

Nowadays, this kind of situation is quite common. The aforementioned young man's identity has evolved in a multilingual and multicultural environment; multiculturalism is the self-evident basis for life, not the situation that should be prepared for.

The same young man mentioned before, who is multilingual, can, for example, handle Finnish in Finland, Estonian in Estonia, and English in England. A person may speak multiple languages, but, based on their language skills, different conclusions can be drawn. To a Finnish native speaker, his Finnish language at least reveals that he is alienated from today's Finnish language, and that he also has a slight accent when speaking Finnish. Language is a sensitive part of identity because it is an individual's tool for dealing with one's identity and also, the surrounding people largely identify themselves and others through their accent (Rannut et al., 2003).

A person's identity and well-being depend on the context in which they are at that moment to a large extent. While in Finland, this young man is often seen as semi-Estonian for the environment, but in Estonia he mainly represents a Finn. According to Pauli Karjalainen (Siim, 2006), the environment can be observed physically-location-wise, sensually-emotionally and sociallyculturally. Our own experience and other people play a great role in how we place ourselves on the map of cultures. Sometimes, when we observe our identity, the meaning of the place and its dimensions are easily forgotten.

\section{Daily choice of the language of the participants}

The following subchapter provides data on the daily use of the language of the research subjects in order to highlight the links between their language and identity.

The home language of participant S1 while living in Estonia is currently both the Erzya and Russian languages. When dealing with friends, she uses mainly Russian, but she also uses Erzya and Estonian. Some of the members of her ethnic group have also settled down in Estonia. However, outside 
the home, she mostly uses Russian and Estonian. When reading the press, she uses Russian and Mordvinian; she does not read Estonian-language press. However, when reading books, she uses Russian, Estonian and Mordvinian. The most preferred language for her is her mother tongue, and this is also where she is most proficient. This participant teaches her child the Erzya language and speaks to him only in the Erzya language; she is of the opinion that a child must know his or her own language and culture of origin. She watches TV shows both in Russian and Estonian.

S1: Russian TV shows interest me more. In my opinion, the Estonian language TV shows are boring.

Since she has been exposed more to Russian TV programs since childhood than to Estonian-language programs, it is easy to figure out that over time, she has developed some favorite shows on Russian TV channels. It can also be assumed that besides the content of TV channels, it is easier for her to follow Russianlanguage programs, thanks to her higher proficiency in Russian.

S2, who also participated in the research, is currently using Russian and Mari as a home language while living in Estonia. While communicating with her friends, she uses three languages: Russian, Mari, and Estonian. Outside the home, she also uses Estonian, Mari or Russian, depending on the communication partner. When reading media, she uses Russian primarily, but also to some extent Estonian. The books she reads have been written in Russian. She predominantly prefers to speak Russian and Mari. As for television, she watches both Russian and Estonian programs. She has a very favorable attitude towards teaching her children their own mother tongue, being of the opinion that one must definitely learn and know their own language of origin. Regarding teaching the Mari language to her children, her opinion was as follows:

S2: Teaching your mother tongue to children is an opportunity to ensure cultural continuity and, after all, culture happens through the language, making it more accessible to those interested in the respective culture.

Participant B1 currently only uses Russian at home and interacts with friends both in Russian and Estonian. He also uses these two languages outside 
the home most. When reading the press, he prefers reading in Estonian and, as the previous participant in the study, when reading books, prefers Russianlanguage books. As for television, he watches both Russian and Estonian programs. He mostly prefers to speak Russian, and this is also where his best language skills lie. At the same time, he has a positive attitude teaching his mother tongue - Komi-Permyak language - to his children. Here too, however, he speaks of favoring the transmission of one's language to the next generation, although, as can be seen, a person may essentially never use his or her language of origin.

However, S3 is currently using the Shoksha language as her home language, whereas when interacting with friends, she uses both the Shoksha dialect, the Erzya, Russian, and the Estonian languages. Outside the home, she uses Russian and Estonian, but to some extent also the Erzya language. It is likely that in this case the Erzya language is used outside the home precisely to communicate with friends in her community. This subject reads Russian, Erzya and Estonian press, whereas while reading books, she uses Russian and Estonian sources. The most preferred languages for speaking for her are Russian and Erzya. Russian can be preferred because in many cases the Russian language can be used successfully in everyday communication, and Russian has also been used as a language of instruction in the country where the participant was born. Therefore, she should have at least a good command of Russian. It is also clear why, as a preferred language for the Shoksha dialect, the Erzya language is mentioned as equal to the Shoksha dialect - this young lady's native languages are both the Erzya language and the Shoksha dialect. S3 also has the best command of these two most preferred languages. On television, she watches TV programs that are in Russian, in Moksha, in Erzya and in Estonian.

A German lady (S4), who participated in the study, is currently using Estonian and a small extent of German in her home - her partner is a young Estonian man who has never learned German, but thanks to S4 he already knows some German words and expressions, and she occasionally speaks German with him. In communicating with her friends, S4 uses both Estonian and German, but outside the home, she uses Estonian. However, she has a relatively small command of Russian: she cannot cope when trying to interact in Russian; she only has a passive skill of Russian. She uses German and 
Estonian for reading journalism, and she also reads books in these two languages, plus English literature. Her most preferred and most proficient language continues to be German. She will undoubtedly want to teach German to her children in the future, because "a child must know his or her language and culture." She watches television in both German and in Estonian.

A young man from the Czech Republic uses the Russian language both at home and with his friends, but outside his home, he also speaks a little bit of Estonian besides Russian. Russian is his primary language for reading the press, but he reads different works in Russian, Czech and English. He mostly prefers to speak Russian, but he is also orally fluent in Czech.

The subject S5, who was born in Estonia and has lived abroad for 16 years, still considers herself an Estonian when abroad. In communication with friends and acquaintances, she mainly uses English, but she also speaks in Estonian when communicating on the internet with friends living in Estonia. Outside the home, she uses English only. However, when reading the press, she uses three languages: English, Estonian and Norwegian. While reading books, she mainly uses English. As for the language preference, the participant has noted that she prefers both Estonian and English equally, although she still knows her mother tongue - Estonian - best. She is also teaching her mother tongue to her child for the following reason:

S5: I want my child to know where his mother's roots are.

This answer shows that this participant takes care of the language continuity developed in the home environment. She watches TV shows on English television, but she also watches broadcasts in Estonian on the Internet and also listens to Estonian radio.

A young man from Finland (B3), who participated in the study, uses Finnish the most in communicating with friends, followed by Estonian and English. Outside the home, he uses mostly Estonian; he does not speak Russian. He reads the press in Finnish but prefers to read books in English. While living in Estonia, he prefers to speak Estonian.

B3: I really like the Estonian language, especially the sound of it. 
Also, his main working language is Estonian. From television shows, he mainly follows programs in his mother tongue, but also in English and to a lesser extent in Estonian.

Based on the results, it can be argued that all participants have added the Estonian language into the selection of the languages used outside the home while living in the new country of residence; since settling down in Estonia, they have learned Estonian to a greater or lesser extent as settlers in Estonia, and the participant living in the UK has also learned English and is currently really proficient in English.

In the present study, 3 of the representatives of the people's kin to Estonians also use their mother tongue as their home language beside the Russian language, only 2 participants have lost their mother tongue over time, but, on the other hand, they did not hear their mother tongue too often even in their childhood home. Thus, the merger with the Russian language has already taken place in the previous generation and is therefore expected in the language choices of the participant. A parallel of the German-born participant can be provided.

Outside the home, the above four participants mainly use Russian, but living in Estonia, they have also learned Estonian and use it as needed. Interacting with each other within one's group, the subjects happily use their own mother tongue, which also shows the endeavor to preserve their minority language and their linguistic sense of belonging. Russian and native language literature, in some cases also Estonian, is preferred when reading the press, but books are generally not read in Estonian; Russian is the dominant language in this field. Russian and the subjects' mother tongues are the most preferred languages. Although, as outlined above, one of the participants did not actively use his mother tongue, however, he has not forgotten it; and all four participants in this group want their children to know the national culture and language of their ancestors, and the extent to which their mother tongue was practiced was not a factor here.

The German lady, who was also a subject of the research, mentioned that she wanted to teach her children German in addition to the Estonian language. She considers teaching the German language (and culture) important because, in her opinion, the child must know her mother's or father's mother tongue and the related traditional culture. The German subject is 
a bearer of a rather strong German language identity. She speaks German with her relatives and relatives living in Germany; she also likes to read German fiction, although in everyday life she is forced to mostly use Estonian, because many Germans living here do not speak German, and she prefers speaking English to speaking Estonian. Her most preferred language is still German, and she also knows her mother tongue at the best level.

However, the young man from the Czech Republic has already lost a lot of his language; he has merged with the Russian community living in Estonia. He prefers Russian to Czech for the very reason that he uses Russian in communicating outside his home and with friends, and he does not have a high level of Estonian. Therefore, his first choice when operating in the Estonian society is Russian. He has lived in Estonia for 13 years since his childhood and studied at a Russian-language school - this has also led him to prefer Russian to his mother tongue.

An Estonian-born participant who has lived in London for years has not strongly moved away from her mother tongue in her heart, so she feels that she identifies herself with her mother tongue. As expected, English has gained a prominent position in her life and communication. She has many friends of different nationalities, and she speaks English with her husband. She teaches her child to speak Estonian, but points out the following:

S5: Although I try to teach my child the Estonian language and vocabulary, the child does not embrace it.

Here, the roots of the described attitude may be hidden in purely practical matters: it is possible that the child feels that because he has nobody to use Estonian with in everyday life - the mother also prefers to use English in communicating with him - it creates a reluctance towards learning the Estonian language. The interviewed mother has clearly stated that she will never return to Estonia for permanent residence. They visit their relatives living in Estonia rarely - once every several years - so this fact obviously does not create any motivation for the child to learn his mother's native language. At the same time, however, the participant in the study states that she firmly wishes her child to learn the Estonian language and not to forget it in the future and be familiar with the culture of his Estonian ancestors. 
When the subject from Finland came to Estonia in 2003, he achieved oral proficiency of the Estonian language with an astonishingly rapid rate over five months, because he was constantly in an Estonian-speaking environment and had a strong incentive to learn Estonian quickly due to his job. His working languages are Estonian and Finnish. With regard to his language preference, he highlights the following:

B3: Although I have a Finnish background, I prefer Estonian to all languages, although it is only my third language besides Finnish and English.

As mentioned above, this participant likes the sound of the Estonian language. But the fact that he lives in Estonia and uses Estonian mostly in everyday communication definitely plays a role in his language preference, and by continually using Estonian he has learned to speak it better and better. Apparently, the similarity of Finnish and Estonian, with the same kind of subjective familiarity, has a role to play in the pleasantness of the language.

Thus, the results show that the acceptance of a language, and the extent of the use of that language, even when distancing from it, or even an attempt to assimilate into the body of speakers of the other language, is the result of the individual's choice. Of course, there are societal factors that guide people more in the choice of languages, such as the demands of the labor market and life experiences, but these factors are complemented by human desires, beliefs, values, and their upbringing, as the key factors.

\section{Ethnic identity and the choosing of identities}

The third part of the study questions consists of the so-called attitudes and self-realization module, in which the respondents were asked, for example, which ethnic identity or identities they carry and to which ethnic group others consider them to belong to in their country of birth. In addition, it became known whether the study subjects would change their identity under any circumstances.

Study subject S1 senses to belong among those Mordvins who live here. She feels her closest culture to be that of the Mordvin culture and its traditions. However, she notes that living in Estonia for 19 years, has slightly 
changed her identity, and an Estonian identity has been added to where before there was none and her Russian identity has strengthened since the subject has a very high proficiency in Russian, and her spoken Estonian accent leads people to believe her to be Russian. This respondent also uses Russian for communication to a great extent. Concurrently, the subject argues that she does not construct her identity based on interlocutors, hence interactions do not affect her choice of identity. At the same, the subject is able to use various languages depending on the preference of her conversation partner, since the subject has a good command of multiple foreign languages. The subject feels proud to belong in her respective ethnic group and thinks she has not been subject to any kind of discrimination while living in Estonia. However, the subject's attitude toward international marriages is not positive.

S1: I think that this is not a good thing.

The respondent did not wish to elaborate on her respective opinion. But since her spouse belongs to a related ethnic group of Estonians, then such a situation may feel natural to her where she can communicate in her mother tongue, and it is also possible that she may take mutual understanding for granted when the interlocutors are of same or similar cultural heritage.

The respondent (S1) does not consider belonging to a religion to be important. The subject does not know whether Estonians have an economic advantage in Estonia (for example, income amount wise, etc.). Concurrently, she is perfectly aware of her three identities - Mordvinian, Estonian, and Russian, but those can vary depending on circumstances. For example, when she is visiting her relatives in her country of origin, she feels a stronger sense of being a Mordvinian, since there, she is considered to belong to that ethnic group and while visiting, she also certainly communicates with her relatives, thus sensing her roots. To the question: "Would you change your identity under certain circumstances?" she replied: "Probably not". The given study subject has never had situations where she would find it hard to define herself linguistically and ethnically. She is fully aware of carrying three identities.

Study subject $\mathrm{S} 2$ answered the question "To which ethnic group do you feel you belong to while living in Estonia?", as follows: "Russian", then she proceeded to strike out the answer and wrote the following: "To no group" and 
followed that text in brackets saying "To mine" and "My own". This response may signal that the study subject may have some difficulties with defining her identity. She also pointed out that her identity has changed a great deal during the last 19 years. At times, the subject constructs her identity depending on the interlocutor, since she thinks that not everyone needs to know to which ethnic group she belongs to and which considers her own. She thinks the following about her own ethnic group:

\section{S2: Every nation must be and live.}

Thus, among other things, she values both major and minor ethnic groups and senses the importance of their survival.

The subject's response to the question concerning discrimination was that she had a negative experience, but she did not go into details about how it manifested. When the subject visits her country of birth, her relatives consider the subject to be a Mari. The subject considers her closest culture traditions to be Mari, then the traditions of their related ethnic group and after that Russian, Estonian, and Finnish customs and traditions. Compared to the previous respondent, she considers religion to be important and she considers herself to follow two religions -1 ) animism and 2) orthodoxy. Her take on international marriages (which again differs from the previous respondent) is positive and she would not be willing to change her identity under any circumstances; however, she has had situations where it has been difficult to identify herself linguistically and ethnically, ergo the borders of her identity have begun to disperse.

Respondent B1 feels that while living in Estonia, he belongs to the Finno-Ugric group and that his identity has changed slightly during the 19 years living here (especially while studying in the university). He chooses his identity based on the situation; for example, depending on his interlocutor. He thinks the following about his ethnic group:

B1: Self-determination level is weak, but there are some signs of growth, even though they are marginal. 
He has some experience with discrimination from both Estonians and those Russians who speak very fluent Estonian. He is assigned a "strict KomiPermyak identity" in his birth country. He considers his closest culture to be that of Komi-Permyak, but at the same time, he has great respect for other Finno-Ugric peoples' cultures. The order of importance of cultural traditions for him are first Finnish, then Estonian, and then Russian. This shows that closeness of traditions has no relation to the language in use since the respondent uses mainly the Russian language, but the importance of Russian folk traditions for him is only fifth. The answer to the question regarding international marriage was that the subject approaches them cautiously. The subject B1 thinks that Estonians in Estonia have certain economic advantages; for example, in finding a job that pays better, etc. He admits that sometimes he claims himself to belong to a different ethnic identity in certain situations (when he thinks that it would be more beneficial). For example, due to pragmatic reasons, he has sometimes claimed to be a Russian to avoid excessive interest and question, since Estonia is not very knowledgeable about related ethnic groups and, thus, he feels uncomfortable being the centre of attention. The subject also mentioned xenophobic social groups where it is prudent to hide his ethnic origin. In order to express some other linguistic affiliation, he changes his language of communication with his interlocutor for this exact reason, but often also out of politeness or in order to blend into a foreign company. He would be willing to completely change his ethnic identity under only very serious circumstances. He has been in a situation once, where it was hard to define himself linguistically and ethnically.

The respondent S3, however, knows exactly that while living in Estonia she belongs rather to the Russian group since she finds that her own community in Estonia is far too small to get a sense of belonging to an ethnic group. Concurrently, she feels internally that her identity has not completely changed while living here. Then again, she feels that she seems to be considered a Russian in Estonia. While living in Estonia and socializing with others, she assumes the identity that she feels to be more beneficial in those moments and picks an identity based on circumstances. She may also pick a language based on the group she socializes with in order to be more easily accepted. Since she is very proficient in multiple languages, an interlocutor 
may not be able to deduce that the identity in use may be constructed for this exact communicative situation. Her thoughts about her own ethnic group include the need to read and write more in her mother tongue so that she would not forget it. She has sensed discrimination towards her while living in Estonia, hence her blending into the society has not been easy. Then again, she also finds that Estonians certainly have an easier time on the job market; but is also confident that finding a better job in Estonia is easier than in her home country.

As mentioned above, her identity of choice amongst the competing identities while living in Estonia is predominately Russian, but while visiting her homeland, she is considered Mordvinian. Arranging folk cultures for herself in the order of importance, her first choice is Mari, then Udmurt, third being Russian and fourth Estonian culture and affiliation to some religion is of high importance to her. She has no prejudice about international marriage, the respondent has a good attitude towards it. She is unwilling to change her internal identity (perhaps the resoluteness of the answer is best described by the "no" answer being underlined). However, she has not had situations where it has been difficult to identify herself linguistically and ethnically. Hence, even though she carries multiple identities, she knows full well who she is, and where she belongs to. Answering the question of whether she has any thoughts about her ethnic or linguistic origins, S3 answered as follows:

S3: The Shoksha dialect is very interesting in the sense that it contains both the 1) Erzya and 2) Moksha languages and language characteristics, and additional elements that are only characteristic to Shoksha language.

Study participant (S4) feels strongly to belong amongst Germans even when living in Estonia, and she has not noticed any identity changes over the years. She does not see a correlation between using different languages in different situations/areas and ethnic self-determination.

S4: Yes, I use Estonian in my home environment and outside it, but I am still a German.

Like most other respondents, she also displays her national pride. 
S4: Germans... are a great nation. I think well about it. And they are family people.

When going to Germany, her aunt sometimes jokingly says: "Our Estonian has returned", but her ethnicity in her homeland is considered to be German.

By comparing Estonian and German cultural traditions, she points out that in her mind there are no great differences between them, and she embraces both cultures as her own. Indeed, it can also be seen historically how the German cultural influence has affected the Estonian culture, therefore it is no surprise, why the respondent feels that Estonian and German cultures are quite similar.

Respondent S4 has a good attitude about international marriages and points out that she too lives with an Estonian man. What she thinks about the privileges of Estonians' on the job market, it is as follows:

S4: It depends on the person and their talents.

This answer can be understood to say that the respondent does not directly think that Estonians have a clear advantage in the society based on their ethnicity or language skills.

Although she has chosen to speak a language spoken in a foreign group to blend in, should she be fluent in it, she answers with a resolute "no" to the question, whether she would be willing to change her identity.

The answer to the last question that allowed the respondents to express their thoughts freely about their ethnic origin or language, was as follows:

S4: At first, when I came to live in Estonia, I understood nothing in Estonian. I did not even understand when one word ends and another begins, in the beginning, everything was very difficult.

All this, however, shows how important motivation and the linguistic environment is in language learning. Since she started to study in an Estonianlanguage school after having moved here, the respondent had to learn Estonian as quickly as possible in order to keep up with others, which was a driving force for gathering all internal resources and give her best in language learning. It 
should be mentioned here, that the responded graduated the school with great success.

A young man coming to live in Estonia from the Czech Republic rather feels that he socially belongs to Russians; however, this may have developed due to the fact that he came to live in Estonia as a child and has, therefore, a weaker bond with his own community. Those who do not know his origins think that he is of Russian descent. Thus, respondent B2 claims that his identity has changed, and that the change started already when he permanently moved to Estonia with his family. He has interacted with Russians for so long and to such an extent, he feels that the competing identity to his Czech one is the Russian identity. Judging by his answers to the questions, he does not change his identity based on the interlocutor and feels an internal belonging to the Czech ethnic group, however, a large part of his identity is the Russian identity that has appeared while living in Estonia. His grandparents and other relatives live in the Czech Republic and while visiting them he is considered to be a Czech. The study subject considers his closest cultural traditions to be both Czech and Russian equally, and he has a positive attitude towards international marriages. He finds himself to be not in a better economic position when compared to Estonians, which may also be related to his proficiency in the Estonian state language. He is a first-year student in the university, where the Estonian language is the study language and his Estonian language proficiency has still improved during that year. Depending on the interlocutor, he may choose to switch languages, but he sometimes likes to stress in conversations that his motherland is actually the Czech Republic. Among other things, it can be concluded that he feels pride over his ethnicity. He does not believe in completely losing his Czech identity at some point but points out that there have been situations in his life where it has been difficult to determine his affiliation.

A study subject, who is a woman, has lived in many countries after having graduated from a high school in Estonia and has for now lived in Great Britain for a long time gives an answer to the question whether her identity has changed in the last 20 years as follows: "Yes it has, since I have lived in various foreign countries. But I do feel like a foreigner everywhere, even while living in London, this feeling has not disappeared". This shows that she does not fully feel she belongs to Great Britain or with the Brits. She still considers 
herself to be an Estonian. At the same time, she does not consider herself to be quite identical to Estonians living in Estonia. In addition, she refers to Estonia as her origin country and homeland, not only just the country of birth but has no plans to return to living in Estonia. She claims not to be dependent on interlocutors to be anyone else but an Estonian and considers the closest culture to be that of Estonian but is willing to switch languages depending on the situation of the interaction, so that the listener would understand her better. Religious affiliation has no importance to her. She has a positive attitude towards international marriages and substantiates this with the following: "Since I too am married to a foreigner". She does not believe that Estonians have any sort of economic privileges. Rather, she believes it to depend on people themselves. The answer to the following question: "Would you be willing to change your identity under some circumstances?" was somewhat surprising. Out of all respondents, she was the only one who would certainly be willing to change her identity, should there be a need for it. She says that she has already had several situations where it is hard for her to determine her linguistic and ethnic affiliation, however she claims her core identity to be Estonian. Then again, when she visits Estonia, she already feels to be somewhat of a foreigner. Since she feels to be a foreigner everywhere, it is possible that she senses internally that she is losing her roots to some extent.

Taking into account the responses of a Finnish respondent, it can be seen that his identity has also changed over time, which is reflected in the following answer:

\section{B3: My identity has changed to be more international.}

It is evident that he senses multiple internal identities. In Estonia, he predominately feels like a citizen of Tallinn and only after the interviewer further specified the questions, he admitted considering himself to be a Finn living in Estonia. He does not identify himself to be identical with the Finns living in his country of birth, but feels that he is accepted everywhere as a Finn and not a foreigner. He would not be willing to change his identity under any circumstances. And the respondent considers his closest culture to be Finnish. 
He thinks that his ethnic group, the Finns, are nice, honest and hardworking people. The respondent has sensed discrimination while living in Estonia, as he thinks Estonians have a negative opinion about the Finns.

B3: Estonians have many stereotypes about Finns.

As it often happens, people develop certain stereotypes about those living in neighbouring countries, which is related to historical exposure. The informant has never chosen an identity dependent on his interlocutor, but if he is proficient in a language, he is willing to change the language of communication with ease, depending on the person and situation. The respondent has a very strong positive attitude towards international marriages, with his argument being his own foreign spouse. The change to a more international identity may be partly caused by the respondent's foreign spouse.

\section{Discussion}

When looking at the findings of the study, it should be emphasised that opinions on identity differed to a great extent. For example, some of the representatives of the Estonian-related languages had a strong identity and linguistic continuity has been preserved for generations, but not all respondents. For example, for the participant whose mother tongue was Mari and who considered themselves to be from the Mari ethnic group, the first language was Russian. The situation was similar for the subject from PermyakKomi and his first language was also Russian. The participant believed that this might be due to the fact that he had spoken Permyak-Komi language only a little and occasionally in his childhood with his mother. These are examples of cases that the mother tongue and the first language may not always match. There was also a similar situation for a young man who settled in Estonia from the Czech Republic, whose mother tongue was Czech but at a weaker level than Russian. He used Russian almost all the time and everywhere, at home and outside of home. At the same time, it is not surprising, as this young man studied in Russian at school from the first grade and was still using it and only used Czech when talking to his mother. 
At the same time, language preservation depends mostly on the language speakers' attitude to their own language, and the number of the language speakers (Kidd, 2002). For example, it was evident that efforts have been made to preserve the ethnic minority language of the young ErzyaMordvinian woman; the same is true of the Shoksha and Erzya dialect, so they have also resisted the attempts of Russification in a situation where, for example, the schooling in their homeland is largely in Russian. In the case of these two participants the linguistic and cultural continuity have been preserved, where knowledge of language and cultural traditions has been passed down from one generation to the next, and the new generation also wishes to move on in the same direction.

A strong German identity was represented by the German participant, who had preserved a strong sense of the German identity and a feeling of belonging to the German people. As a representative of a large nation in Estonia, he probably does not have to worry about the preservation and conservation of his language and culture, as is more likely in case of minorities.

An Estonian, born in Estonia, but changing her country of residence said that she has already developed two competing linguistic identities: Estonian and English. She explained this as follows: as she only uses English in everyday life, she associates herself with this language, and she also mainly thinks in this language. Originating from a bilingual family, her second language was Russian, which she used to interact with her father, but by now the Russian language has been pushed further into rank three after Estonian and English as she no longer has the need to use Russian. But she uses English every day and, to a large extent, as a home language, whereas 19 years ago she did not speak the language at all. Her linguistic identity has changed over time.

The young man born in Finland also pointed out that he carries several identity components and, while living in Estonia, he feels that he has become more international, and the boundaries of his identity are becoming blurred. He feels that he carries the identity of several nations.

In one way or another, self-perception and attitudes are influenced both by the requirements of adaptation to practical life, by experience and by the affective component - feelings. Cognitive perception processes affect thinking and thus also behaviour and self-perception. 


\section{Conclusions}

Based on the responses to the third module of questions it can be argued that distancing from the compatriots living in their country of birth has taken place, meaning that there is no longer a sense of complete oneness with them, although they all continue to be viewed in their country of origin as fellow compatriots. Over time, several of the individuals who were studied have acquired a new identity when integrating into Estonian society - an Estonian identity.

Some of the representatives from nations cognate to Estonia have sensed that they are viewed like Russians in Estonia, since they use the Russian language more often when living here, and that they speak it at a very good level (the Estonian language was learned later, only when they moved to Estonia). At the same time, there were also respondents from outside of nations cognate to Estonia who felt that it is not always a wise decision to reveal their ethnic origin in certain situations. There have also been instances where a situation-based identity has been constructed for themselves, based on practical considerations. In general, there is a lack of readiness to change their identity, although a couple of the interviewees would be ready to do so for very good reasons. This shows that, inwardly, individuals who have assimilated or are currently assimilating have no desire to lightly abandon their identity.

It is evident from the results of the study that the initially clear ethnic and linguistic identity of a number of informants has become blurred after switching home countries, whereas parallel identities have been constructed in addition to the initial identity, which the individual considers to be his or her own at a different level. Some of the interviewees have encountered situations in life where they have found it difficult to determine their affiliation. This illustrates once again the multiplicity of identities, the plurality and the multifaceted nature of competing identities. In some instances, it may seem like the interviewee is, based on their nature, inherently a cosmopolitan citizen, unconcerned if they lose their roots or even living a rootless existence.

In today's post-modern world, where the majority of people carry multiple identities, it is often difficult to identify oneself, with cosmopolitanism having also spread further than ever before. This is one of the reasons why it 
should be taken into consideration that future generations should also be aware that they are the representatives of a multicultural future society, and that alongside the development of their national identity it is important to develop the necessary attitudes and personal characteristics required for coexistence. It is possible that this would lead to a reduction in the number of incidents of intolerance and discrimination, which, unfortunately, remain rather a commonplace in present day Estonian society. It is very important that everyone feels like they are accepted as citizens, particularly in the country in which they are living. This requires an intercultural dialogue as well as a knowledge of languages.

\section{References}

Abu-Hanna, U. (2007). Sinut. Helsinki: WSOY.

Baker, C. (2006). Foundations of Bilingual Education and Bilingualism, ( $4^{\text {th }}$ ed.). Multilingual Matters.

Barth, F. (1969). Introduction. In F. Barth (Ed.), Ethnic Groups and Boundaries: The Social Organization of Culture Difference (pp. 9-38). Prospect Heights, IL: Waveland Press.

Bilaniuk, L. \& Melnik, S. (2008). Atense and shifting balance: Bilingualism and education in Ukraine. International Journal of Bilingual Education and Bilingualism, 11(3, 4), 339-372.

Doan, G. O. \& Stephan, C. W. (2006). The functions of ethnic identity: A New Mexico Hispanic example. International Journal of Intercultural Relations, 30(2), 229-241.

Eschbach, K. \& Gómez, C. (1998). Choosing Hispanic identity: Ethnic identity switching among respondents to high school and beyond. Social Science Quarterly, 79, 74-90.

Fishman, J. A. (2001). Handbook of Language and Ethnicity. New York, Oxford University Press.

Gustavsson, B. (2000). Haridus kaasajal. Eesti Vabaharidusliit. Tõravere Kirjastus.

Hoffmann, C., \& Ytsma, J. (Ed). (2004). Trilingualism in Family, School, and Community. Language Arts \& Disciplines. Multilingual Matters, England. 
Iskanius, S. (2005). Venäjänkielisten maahanmuuttajaopiskelijoiden kieliidentiteetti. Jyväskylä: Jyväskylän Yliopisto.

Kidd, W. (2002). Culture and Identity. New York: Palgrave.

Küün, E. (2014). The Impact of the Change on the Extent of the Language Shift in the Language Environment in the Context of Linguistics. International Journal of Global Ideas, 3, 5-43.

Liebkind, K. (1995). Dispersial Xenophobia and Acculturative Stress. Refugees in Finland. In J. Hjarnø (Ed.) Multiculturalism in the Nordic Societies: Proceedings of the 9th Nordic Seminar for Researchers on Migration and Ethnic Relations: Final Report (pp. 261-273). Copenhagen: ThemaNord.

Loide, A. (2015). Eestis elavate muukeelsete perede vanemate suhtumine oma lapse kakskeelsusesse ja etnilise identiteedi kujundamisse. [Magistritöö] Tartu.

Muldma, M. (2009). Kasvatus mitmekultuurilises keskkonnas / Education in Multicultural Environment. Teadusartiklite kogumik. Tallinn: Tallinna Ülikooli kirjastus.

Paasi, A. (1997). Piirid üleilmastuvas maailmas: poliitilise geograafia vaatenurgast. In V. Saarikoski (Ed.), And never shall they meet? European Space and Thought Between East and West (pp. 22-34). Turku: The Department of Political History, University of Turku.

Phinney, J. S., Dupont, S., Espinosa, C., Revill, J. \& Sanders, K. (1994). Ethnic identity and American identification among ethnic minority youths. In A. M. Boury, F. J. R. van de Vijver, P. Boski, \& P. Schmitz (Eds.) Swets and Zeitlinger: Lisse (pp. 167-183).

Rannut, M., Rannut, Ü., \& Verschik, A. (2003). Keel, võim, ühiskond. Tallinn: Tallinna Pedagoogikaülikooli kirjastus.

Rousseau, D. L. (2006). Identifying threats and threatening identities: The social constructivism of realism and liberalism. Stanford University Press.

Sein, A. J. (2004). Confronting political violence: Reexamining the influence of threat perception on policy responses to internal discord. Presentation in Rice University Undergraduate Research Conference 2004. 
Siim, P. (2006). Paikkasuhteet maahanmuuttajien kertomuksissa. In S. Knuuttila, P. Laaksonen, \& P. Piela (Eds.) Paikka. Eletty, kuviteltu ja kerrotu (pp. 93-109). Helsinki: SKS.

Smith, P. K., Cowie, H. \& Blades, M. (2008). Laste arengu mõistmine. IV väljaanne. Tallinn: Tallinna Ülikooli kirjastus; Blackwell Publishing.

Smith, J. M. (2016). Creating New Identities: Chinese American Women Professionals in Greater Baltimore. Advances in Anthropology, 6(2).

Sudman, S., Bradburn, N. M. \& Schwarz, N. (1996). Thinking about answers: The application of cognitive process to survey methodology. San Francisco, CA: Jossey-Bass.

Tabouret-Keller, A. (2000). Language and identity. In F. Conlmas (Ed.), The Handbook of Sociolinguistics (pp. 315-326). Oxford. Blackwell Publishers.

Toivanen, T. (2009). Teatterilähtöiset menetelmät ja nuoren identiteetti. Kasvatus mitmekultuurilises keskkonnas / Education in Multicultural Environment. Teadusartiklite kogumik. Tallinn: Tallinna Ülikooli kirjastus.

Uudeberg, T. (2009). Julgeolekuidentiteedi seos ohu tajumisega. David L. Rousseau' konstruktivistlike seisukohtade testimine. [Magistriväitekiri.] Sotsiaalteaduskond. Riigiteaduste instituut. Tartu: Tartu Ülikool. Retrieved from http://www.google.ee/search?hl=ru\&source= $\mathrm{hp \& q}=$ uudeberg+identiteete\&aq=f\&aqi=\&aql=\&oq=\&gs_rfai= .

Valk, A. \& Karu, K. (1999). Attitudinal and behavioural attachment to the group: Symbolic and concrete ethnic identity. In M. Lauristin, \& L. Rahnu (Eds.), Intercultural Communication and Changing National Identities (pp. 73-87). Tartu: Tartu University Press.

Valk, A. (2017). Identiteet avatud maailmas. Eesti inimarengu aruanne 2016/2017. Retrieved from https://inimareng.ee/static_assets/pdf/EIA\%202016\%E2\%80\%9317 \%204.5.\%20Identiteet\%20avatud\%20maailmas.pdf.

Vasama, J. (2003). Lapsen kansallinen identiteetti Virossa. Virolaislapsen kansallinen identiteetti, sen kehittyminen ja yhteys minäkuvaan. Turku: Turun Yliopisto. 
Vseviov, D. (2009). Kultuuride dialoog - võimalus ja paratamatus. In M. Muldma (Ed.) Kasvatus mitmekultuurilises keskkonnas / Education in Multicultural Environment. Teadusartiklite kogumik. Tallinn: Tallinna Ülikooli kirjastus.

Waters, M. C. (1990). Ethnic Options: Choosing Identities in America. University of California Press.

Wendt, A. (1995). Anarchy is what states make of it: the social construction of power politics, in International Theory: Critical Investigations. MacMillan.

White, B. P. (1998). Decision-making analysis. In P. D. Williams, D. Goldstein, \& J. Shafritz (Eds.), Classic Readings of International Relations. Fort Worth: Harcourt Brace College Publishers. 


\section{Elvira Küün}

Tartu universiteto Narvos kolegija, Estija; elvira.kuun@ut.ee

\section{IMIGRANTY TAPATYBĖS IVAIRIALYPIŠKUMAS IR KONSTRAVIMO ASPEKTAI}

Santrauka. Šiame straipsnyje pateikiama tapatybès konstravimo individualiu lygiu apžvalga. Šio straipsnio tikslas buvo nustatyti tyrimo dalyviu etninę tapatybę, kaip kalbinès tapatybės priemonę naudojant daugiausia kalbos pasirinkimo aspekta, taip pat apžvelgti kalbinio tapatumo pasirinkimo priežastis, etninès tapatybès funkcijas iš tiriamojo poziciju ir tapatybès pakitimo arba samoningo pakeitimo laike ar išlaikymo nekintančio priežastis. Žinoma, kad šiandieniniame pasaulyje, vis labiau silpnejjant valstybės sienoms, daugiakultūriškumas ir daugiakalbystė yra iprastas reiškinys. Niekas jau seniai neginčija, ar reikia mokytis kalbu, ir neabejoja, ar turètume bent trumpai pasidomèti apie šalia mūsu gyvenančiu žmoniu kultūra. Tuo pačiu metu, daugiakultūriškumas taip pat sukelia iššūkius, o kartais ir itampa (Muldma, 2009). Suvokimas, kas esi, t. y. tapatybè, gali pasireikšti per ivairius aspektaus, pavyzdžiui, išvaizda, asmenybę, sugebejimus, lyti ir etninę grupę. Kalbant apie etninę tapatybę, pastebeta, kad vaiko susivokimas, jam augant, kinta. Suvokimas apie savo tautybę vystosi kartu su supratimu apie kitus (Smith et al. 2008, p. 195). Žmogaus požiūris ir vertybès susiformuoja vaikystèje, tad prisitaikyti prie visa ko, kas nauja, jam reikia laiko; visi pokyčiai reikalauja vidinio žmogaus vadovavimo, o kai kurie didesni - net visuomenès isikišimo. Atliekant ši tyrima, naudoti pusiau struktūrizuoti interviu.

Pagrindinès sąvokos: etninè tapatybè; "tapatybès perjungimas"; imigracija; kalbos pasirinkimas; tautiniu mažumu kalbos. 